\title{
Relation between tourism and leisure sport habits in the Szolnok College students' circle
}

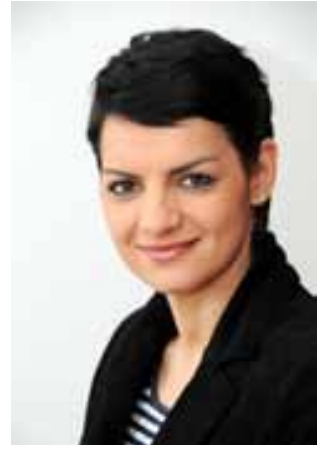

\author{
Szerző: Orsolya Savella \\ College of Szolnok, \\ Department of Tourism and \\ Catering, Szolnok \\ savellao@szolf.hu
}

Abstract: According to a survey made in college students' circle, there is - however at a low level - positive connection between the sporttourism consumers' general health status (Cramer's 0.089) and their satisfaction with their life (Cramer's 0.114).

The aim of this study was to explore further additional correlations. The questionnaire $(\mathrm{N}=360)$ permitted the analysis not only of sport tourism but also general tourism habits. I investigated statistic data of general tourism, those within this physical activity habits and also additional statistic methods. I got further correlations such as leisure sport activities of tourists and the effects of sporttourism activities for leisure time activities at home.

Key words: tourism, sport activities, leisure, lifestyle

\section{INTRODUCTION}

Regular physical activity is one of the determinant factors of health behaviour. Since recreational sports that done for relaxation has significant effect for prevention, intervention and improvement of life quality, it is important to explore the facts that influence the first steps and future continuance of sport activity (Gémes, 2006). One of these factors is tourism as being connected with several elements of life quality (Michalkó, 2010.) and health behaviour (Blair et al, 2001.) as well. Travelling - even for the simple reason of changing place - has important physiological influence over organism, the effect can be strengthened (Michalkó, 2010.) by consumption of different touristic products like health-, active- and sporttourism. Tourism, being one of the most significant substantial forms of leisure time utilization (Fritz, 2011.) ensures opportunities for participation in sport activities, having a permanently increasing importance also for society and economy. Leisure sport as a segment of tourism means the complex entirety of the physical activity done in leisure time to create a qualitative life. The activity that includes games, entertaining exercises, contributes to the condition and the abilities as well. Furthermore, it gives possibility for self-development and is of primary importance from the point of view of public health. (Neulinger, 2003.) As for the function, it can be means to achieve numerable purposes. It can contribute to the physical and mental health of current society, the improvement of public relations and promotion of socio-economical activities. Sports as a part of tourism can relatively increase its influence on development trends above and the experiences while travelling, have got an additional effect on quality of life (Kovács, 2007.), so sporttourism activities can be one of the remarkable bases of healthy leisure habits and can also exist as a chance for healthy life style. There is a significant increase in interests in active tours. The most popular journeys are those that provide opportunity to participate in various sports and recreational activities (Puczkó, 2000.) From this point of view the fact's relevance cannot be denied since participation in tourism, related sport activities, surely increases the odds to permanent home practice contributing to self-development, state of health (Gémes, 2006.) and life quality (Torkildsen, 2005.). Some further demands for additional contexts have been raised due to the results of the published facts (Savella, 2013) based mainly on the general habits of sport tourism. Cramer's value $(\mathrm{V}=0.089 ; \mathrm{V}=0.114)$ by former studies, through slightly but confirmed the fact that average consumers of active and passive sport tourism are satisfied with their general state of health and their general way of life. But the researches mentioned did not cover information about secondary sport motivation (Douglas et al. 2002.) and also did not cover additional information about leisure time activities at home after having experienced some sport activity practised or newly tried while travelling. Aim of this study is to discover and to compare students' habits in tourism and leisure time activities.

\section{Questions and hypotheses}

Questions are defined as follows:

-What is the rate of students' participation in tours in 3 years' period? -Did they practice any sport activity while travelling?

-Is there any coherence between in-travel and post-travel activities?

Hypotheses:

-In 3 years' period great majority of students participated in tourism travelling.

-During their trips greater part of them practised some sport activity. -Sport activities that were practised or newly tried during their trips have significant effects for their future leisure activities.

\section{Method}

Collection of data was carried out personally with a questionnaire in College of Szolnok last year (2013). The participants of the study were full-time, correspondent and distant learner students majoring from tourism and catering, finance and accounting, international business, commercial - marketing department. Questionnaires were filled up by 270 woman and 90 men in Szolnok and also in Budapest in order to be adapted to students on distant course. $94 \%$ of the participants was 18-24 year-old, 5\% 25-34 year-old and less than $1 \%$ belonged to the $35-44$ year-old range. The questions that were divided into 3 groups (leisure time activities, sport tourism habits, quality of life) investigated the features of the students' tourism habits and their leisure time activities. Beside questions of demography, the questionnaire - in a form of opened and closed questions - included 17 points made directly for database, were grouped by targets we framed, in accordance with our aims referred to literature mentioned. The answers were computerized by SPSS 20.

\section{Results}

The graph below shows the summarized statistical results of travelling habits. All of closed questions contained alternative, yes or no answers. Column diagrams demonstrate tourism trips, sport 
activity and leisure sport habits, separately. According to the results, in the period of last 3 years, $79.9 \%$ of the tested students took part in touristic trips, $40 \%$ of them practised some sport activity where the datum given doesn't mark primary or secondary motivation of activity. Additional results show all students' sports habits, i.e. $75 \%$ of them do sports in leisure time.

Diagram No.1.

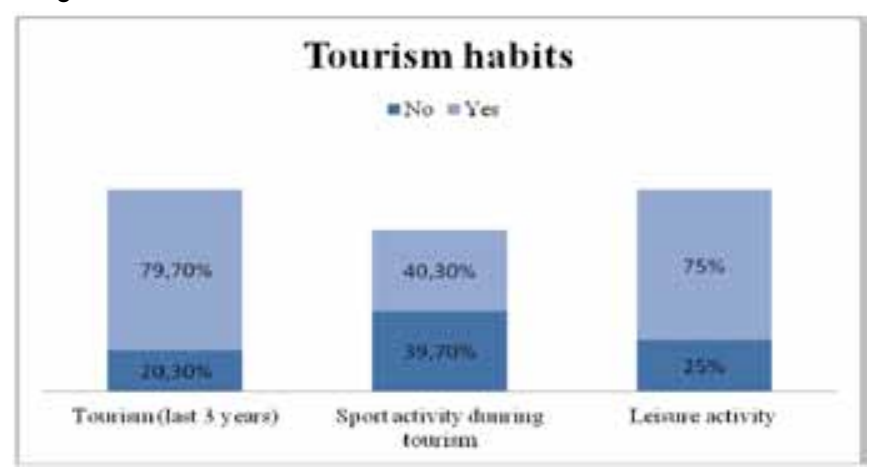

By own database

Diagram No. 2. demonstrates the forms of sport activities during leisure time and travelling. Both question groups contained opened and closed opportunities, equally. The tested students were allowed to nominate other sport activities over predetermined responses. Beyond practised sport activities' type and distribution of percentile occurrence there is an obvious separation in appearance of significant sport activities connected closely to tourism. The disappearance noticed in the periods of leisure is considered to be result of the absence of natural and built conditions, above all, probably, these are the elements of seasonal sport groups. Activities appertained to other category were similar. Utilized opportunity of opened answers, in this category characteristic tourism and leisure time activities appeared like rowing, indoor climbing, table-tennis, roller and body building.

Diagram No.2.

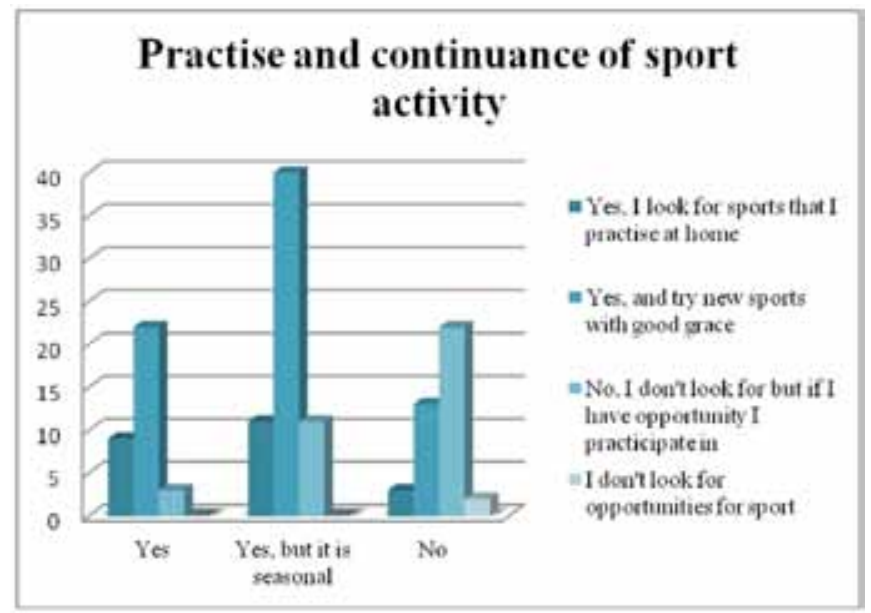

By own database

Table (No.1) shows coherence between sport activities while travelling and during leisure time. The relationship above depends on supposed criteria between the qualities. In this case connection between two test were demonstrated by associational analysis. Strength of connection is shown by Cramer's V: 0.640 . The figure shows an indirect connection that is stronger than average. According to this result it is ascertainable that criteria mentioned are not independent because $64 \%$ of examined students practise sports activity that tried during their trip, under home circumstances, too. This is supported by contingency coefficient: 0.73 and also value of Kappa: 0.656 . The latter value shows an agreement measure of $0.61-0.8$, in this case it is considered to be established one.

Table No.1.

\begin{tabular}{|c|c|c|c|c|c|}
\hline \multicolumn{6}{|c|}{ Symmetric Measures } \\
\hline & & Value & $\begin{array}{c}\text { Asymp. Std. } \\
\text { Erres" }\end{array}$ & Approx $T$ & $\begin{array}{l}\text { Appro } \\
x . \text { Sig. }\end{array}$ \\
\hline \multirow{3}{*}{ Nominel by Nominal } & 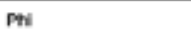 & 1,109 & \multirow{5}{*}{.08s } & \multirow{5}{*}{19.249} & .000 \\
\hline & Cramer's $V$ & .540 & & & .000 \\
\hline & Corengency Coefliclent & .743 & & & .000 \\
\hline Measure of Agrecenert & Kespe & .566 & & & .000 \\
\hline Nof vided Casas & & 30 & & & \\
\hline
\end{tabular}

By database

Based on the associational analysis we can declare a connection of above average between sport activities during travelling and under home circumstances. However, I can't get an answer if the post-travel activity was motivated by the former way of life or the experiences occurred on travelling.

Diagram No.3.

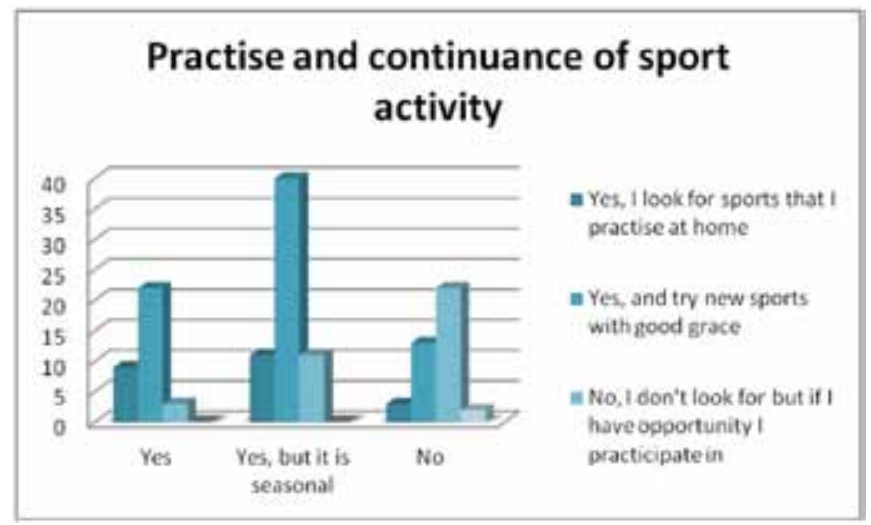

By database

The exploration of further coherences needs a more complex way: correspondence analysis. By this method the differences or connections in variables can be analyzed. For this examination we used the same two closed questions that contained attitude to sport activities under in-travel and post-travel circumstances. Answers were predetermined.

Answers for question of "Do you look for sport activities during tourism?" were "Yes, I look for; Yes, I look for and also try new sports readily; No, I don't look for but occasionally I participate in; No, I don't look for." Other question of comparison was "Did you have any chance for practising sport activity tried during tourism?" Answers for this question were: "Yes; Yes, but is seasonal; No" In case of these variables we examined separately the connection between row and column points. Since we wanted to make comparison results of database we used the way of normalization. 
Table No.2.

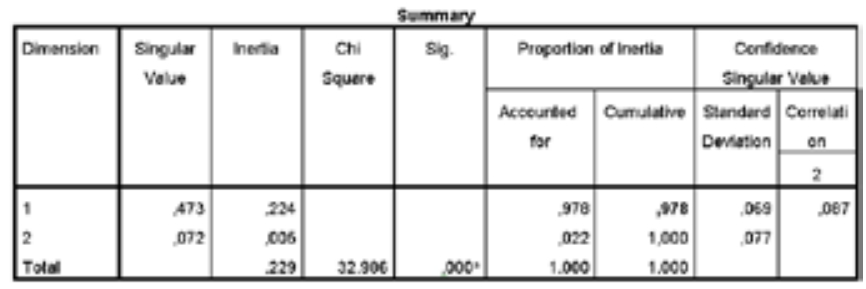

a. 6 degrees of freedom

Accordance with table (No.2.) the absolute inertia value: 0.229 is sample of dimension importance. Already the first dimension bears over $97 \%$ of absolute inertia. He, who looks for physical in-travel activity is inclined to practise also in future, as it is established in virtue of diagram points.

\section{Conclusions}

Aims were to investigate and explore the factors that can have effect on starting and continuance of different sport activities. Beside it I wanted to introduce and compare students' tourism and leisure habits. I intended to get satisfactory answers to the questions about the existing influence segments of practiced sport activity during travelling. Existence of relationship is certified and at this point necessity of further study occured. Accordance with general characterization tourist is a person who is satisfied with superficial impressions received from other people and may be satisfied with a simple test-level (Puczkó et al. 2002), however, to avoid generalization we have to pay attention to the effects for attitude. Experiences offered by tourism attractions include combination of interactivity, learning, and entertainment thus these factors beside pleasure and having a rest, also include the opportunity for education (Puczkó et al. 2000). The results of tested students show that among tourists that do sports with secondary motivation there are people who do look for sports activities and at the same time, there are people who do not look for but occasionally participate in. Participation in tourism attractions included sports activities can contribute to improvement of abilities and that of a special knowledge so it will surely be fixed as permanent experience with influence on spending post-travel leisure time. Assumptions that framed in introduction were certified for existence of relationship is supported by results given. For the more accurate and special study, we need to compose the further questionnaires in a way that assures us getting all the available information about effect of tourism on sports activity. Students who do sport regularly pay increased attention for healthy nutrition (Savella et. al, 2010) and this positive attitude towards sports amplifies leaving negative behaviour (Marcus et al. 2000) or habits like smoking. Based on these results, the relationships and connections above would be important in changing the factors such as nutrition, physical activity and stress management that closely connected to tourism products and since being like his, can ensure an opportunity for an altered life style in a healthier way.

\section{Summary}

In this study I demonstrated the connection of tourism and leisure habits. I investigated and showed issues that can be influential factors in leisure time activities. Regarding leisure time sports activities as important elements of health development and substantial factor in National Tourism Strategy I considered as of importance some other interventional segments that contribute to enhancement of active leisure and well-being. This research confirmed our former assumptions that are ones being able to give basis for further studies, which tourism can be investigated in, as a factor of active leisure in order to create a healthier society.

\section{REFERENCES}

1. Bess H. Marcus - Patricia M. Dubbert - LeighAnn H. Forsyth - Thomas L. McKenzie - Elaine J. Stone - Andrea L. Dunn - Steven N. Blair (2000): Physical activity behavior change: issues in adoption and maintanance, Health Psychology, Vol. 19. No.1 (3241)

2. Douglas Mechele Turco - Toger Riley - Kamilla Swart (2002): Sport tourism, Fitness Information Technology, ISBN 1-885693-43-5, Morgantown 9p. 16p.

3. Péter Fritz (2011): Rekreáció mindenkinek I. (2. javított, bővített kiadás) Bába kiadó, Szeged, p.218.

4. Katalin Gémes (2006): Sport és életminőség In. Kopp Mária - Kovács Mónika Erika (szerk.): A magyar népesség életminősége az ezredfordulón, Semmelweis Egyetem Magatartástudományi Intézetének tudományos iskolája, Semmelweis Kiadó, Budapest 167p, 168p.

5. George Torkildsen: Leisure and recreation management, Routledge, London and New York, 210.

6. András Jánosa (2001): Adatelemzés SPSS használatával, Computerbooks, Budapest. p.108.

7. Balázs Kovács (2007): Életminőség, boldogság, stratégiai tervezés, Polgári Szemle, 3. évf. 2. Szám

8. Gábor Michalkó (2010): Boldogító utazás - a turizmus és az életminőség kapcsolatának magyarországi vonatkozásai, MTA Földrajztudományi Kutatóintézet, Budapest, 33p., 51p.

9. Nemzeti Turizmusfejlesztési Koncepció 2014-2024. Nemzetgazdasági Minisztérium. http://www.kormany.hu/ download/8/41/11000/NTK.pdf Letöltés ideje: 2014. március 18.

10. Ágnes Neulinger (2003): Ahol nincsenek vesztesek http:// www.nemzetisport.hu/sportpolitika/20030417/ahol nincsenek vesztesek Letöltés ideje: 2014. március 17.

11. László Puczkó - Tamara Rátz (2000): Az attrakciótól az élményig - A látogatómenedzsment módszerei, Geomédia Szakkönyvek, ISBN 963-7910-77-8 Budapest, 51p.

12. László Puczkó - Tamara Rátz (2002): A turizmus hatásai, Aula Kiadó Kft., ISBN: 963934589

13. Orsolya Savella - Csilla Kalmárné Rimóczi (2010): Health awareness of college students. International Conference on Tourism and Sport Management, Debreceni Egyetem ISBN 978-963-473378-2

14. Orsolya Savella - Katalin Gaálné Starhon : Sportturisztikai szokások hatása a szubjektív életminőségre. A komáromi Selye János Egyetem 2013-as „Új kihívások a tudományban és az oktatásban" NemzetköziTudományos Konferenciájának tanulmánykötete. 2013. pp. 276-282. ISBN 978-80-8122-074-6

15. Steven N. Blair - Yiling Cheng, J. Scott Holder (2001): Is physical activity or physical fitness more important in defining health benefits. Medicine \& Science in Sport \& Exercise, 2001. Jun. 33 (6suppl): S 379-99 